\title{
Pendampingan Administrasi Dan Sistem Pencatatan \\ Laporan Keuangan Sederhana Pada Pelaku Usaha Mikro Kecil Di Desa Pengulu Kecamatan Sidayu Kabupaten Gresik
}

\author{
Tri Ariprabowo ${ }^{1}$, Moch. Munir Rachman ${ }^{2}$, Moh Afrizal Miradji ${ }^{3}$, Nurdina ${ }^{4}$, Sigit \\ Prihanto Utomo 5 . \\ ${ }^{12}$ Program Studi Manajemen Fakultas Ekonomi Universitas PGRI Adi Buana Surabaya \\ ${ }^{345}$ Program Studi Akuntansi Fakultas Ekonomi Universitas PGRI Adibuana Surabaya \\ E-mail : tri.ariprabowo@unipasby.ac.id
}

\begin{abstract}
ABSTRAK
Kegiatan pengabdian kepada masyarakat yang dilakukan oleh Tim Proram Studi Manajemen Fakultas Ekonomi Universtas PGRI Adi Buana Surabaya dilaksanakan pada bulan Februari sampai dengan Maret 2020, bertempat di desa Pengulu Kecamatan Sidayu Kabupaten Gresik telah memberikan sumbangan yang sangat berarti bagi warga masyarakat khususnya diwilayah desa pengulu kecamatan sidayu kabupaten gresik mendapat sambutan yang sangat baik dan antusiasme yang tinggi. Sosialisasi administrasi dan system pencatatan laporan keuangan sederhana pada pelaku usaha mikro kecil di Kabupaten Gresik ini merupakan salah satu cara untuk membantu pelaku usaha mikro kecil, sehingga diharapkan dengan sosialiasi ini dapat dijadikan sebagai langkah awal untuk memperbaiki kondisi usaha mikro kecil di desa pengulu. Para peserta sosialisasi memeliki kemauan yang besar untuk mendapatkan informasi dan pengetahuan mengenai administrasi dan system pencatatan laporan keuangan sederhana, mengetahui laporan laba rugi dan laporan keuangan sederhana lainnya. Beberapa kendala yang dihadapi pada saat sosialisasi administrasi dan system pemcatatan laporan keuangan sederhana pada peaku usaha mikro kecil di desa pengulu kecamatan sidayu kabupaten gresik ini adalah keterbatasan waktu dikarenakan terbentur dengan aktivitas para pelaku usaha mikro yang kebanyakan adalah petani, dimana aktivitas mereka dimulai dari pagi-sore, sehingga tim sosialisasi agak repot untuk menyesuaikan waktu yang cocok.
\end{abstract}

Kata Kunci: pencatatan keuangan sederhana, usaha mikro kecil

\begin{abstract}
Community service activities carried out by the Management Study Team of the Faculty of Economics at the University of PGRI Adi Buana University Surabaya were carried out in February to March 2020, located in the village of Pengulu, Sidayu District, Gresik Regency, which has made a very meaningful contribution to the citizens, especially in the area of the village governor, Sidayu subdistrict. Gresik Regency received a very good reception and high enthusiasm. The socialization of administration and the system of recording simple financial statements for micro small business operators in Gresik Regency is one way to help micro small business entrepreneurs, so it is hoped that this socialization can be used as a first step to improve the condition of small micro businesses in the village of pengulu. Participants in the socialization have a great willingness to obtain information and knowledge about the administration and recording system of simple financial statements, knowing profit and loss statements and other simple financial statements. Some of the obstacles faced during the administration socialization and simple financial statement recording system for small micro businesses in the village of pengulu, Sidayu sub-district, Gresik, were time constraints due to collision with the activities of micro entrepreneurs, mostly farmers, where their activities began in the morning-afternoon, so the socialization team was rather busy adjusting the time that was suitable.
\end{abstract}

Keywords: simple financial records, small micro businesses 


\section{PENDAHULUAN}

Saat merintis sebuah bisnis walaupun bisnis kecil tentunya ingin berjalan dengan baik dan mendapatkan profit dari bisnis yang dijalankan. Namun untuk mencapainya memang tidak mudah, banyak yang harus dipersiapkan dan lakukan, mulai dari menyusun strategi pemasaran, manajemen SDM hingga yang paling penting adalah manajemen keuangan dengan langkah membuat laporan keuangan. Laporan keuangan merupakan informasi akuntansi paling krusial yang mengendalikan seluruh aktivitas finansial perusahaan.

Kecamatan Sidayu merupakan salah satu kecamatan dari 18 kecamatan di Kabupaten Gresik. Kecamatan Sidayu merupakan bekas Kadipaten Sedayu yang merupakan Kadipaten bekas Kecamatan Belanda dengan adipati yang dikenal bernama Kanjeng Sepuh Sedayu. Meski hanya sebuah kecamatan namun Kecamatan Sidayu memiliki bangunan-bangunan tua yang cukup megah dan alun-alun yang cukup luas. Kota santri adalah sebutan dari Kecamatan ini dan sebagai ikon Kabupaten Gresik. Hal ini dikarenakan ratusan pondokan kecil (pesantren anak-anak) tersebar di seluruh penjuru Sidayu. Secara kultural, kehidupan di Sidayu ini adalah islami secara sosial-masyarakat, ekonomi, politik dan hukum (Sidayu City Explore, $t \mathrm{t}, \mathrm{a}$ ).

Perekonomian daerah ini banyak ditopang oleh sektor ekonomi perdagangan barang dan jasa. Masyarakat Sidayu banyak ditopang oleh sektor wiraswasta, salah satunya industry konveksi/garmen. Hasil utama dari Kecamatan Sidayu ini adalah walet. Selain itu hasil perikanan juga cukup mengalami peningkatan secara signifikan, baik perikanan laut maupun tambak (Sidayu City Explore, tt,b).

Salah satu desa yang ikut berperan memajukan kecamatan Sidayu adalah Desa Pengulu dari total 21 desa (Kabupaten Gresik, 2019). Produk unggulan dari desa ini adalah krupuk ikan, bonggolan, minuman temulawak dan minuman kedelai. Usaha tersebut merupakan usaha yang dilakukan untuk meningkatkan sektor produksi UMKM di desa tersebut. Sedangkan hasil tambak yang dibudidayakan adalah bandeng. Namun dalam pembuatan laporan keuangan terutama dalam penerapan akuntansinya, masyarakat Desa Pengulu perlu memiliki strategi agar pengeluaran tidak melebihi pendapatan sehingga diharapkan dapat maksimal dan menjadikan perekonomian Desa Pengulu dapat meningkat.

Oleh karena itu untuk membantu mengatasi hal tersebut, tim Pengabdian Pada Masyarakat (PPM) Fakultas Ekonomi UNIPA Surabaya melakukan kegiatan PPM di Desa Sidayu, Kabupaten Gresik. Diharapkan dengan dilakukannya kegiatan pengabdian di desa tersebut masyarakat dapat meningkatkan perekonomian desa. Tema dari kegiatan PPM ini adalah "Pendampingan dan Sosialisasi Administrasi dan Sistem Pencatatan Laporan Keuangan Pelaku Usaha Mikro Kecil Di Desa Pengulu Kecamatan Sidayu Kabupaten Gresik" dengan harapan dapat memberikan solusi mengenai perhitungan dan pengelolaan biaya-biaya agar dapat dibuat suatu laporan keuangan yang lebih baik sehingga perekonomian desa dapat meningkat. 


\section{METODE PELAKSANAAN}

Pelaksanaan kegiatan pengabdian kepada masyarakat di desa Pengulu Kecamatan Sidayu Kabupaten Gresik dimaksudkan untuk membantu kepada masyarakat khususnya bagi para pelaku usah mikro kecil tentang Administrasi dan sistem pencatatan laporan keuangann sederhana.Penyuluhan dan pendampingan dilakukan dengan target utama adalah kelompok pelaku usaha mkkro kecil, ibu ibu pkk dan pemuda atau karang taruna yang dapat membantu meningkatkan perekonomian masyarakat luas. Oleh karena itu untuk memberikan solusi permasalahan, maka dilakukan hal-hal sebagai berikut:

1) Melakukan koordinasi teknis di lapangan dengan kepala desa Pengulu Kecamatan Sidayu Kabupaten Gresik, untuk mempersiapkan kegiatan yang akan dilaksanakan.

2) Dari setiap rukun warga (RW) yang terdapat di Desa Cisaat diharapkan mengirimkan utusan peserta pendampingan/penyuluhan.

3) Penyuluhan dilaksanakan di aula bale desa dan diikuti oleh peserta rata-rata 30 sampai dengan 60 orang yang merupakan perwakilan dari setiap RW yang ada di Desa Pengulu.

4) Materi penyuluhan disusun oleh Tim Pelaksana Pengabdian Kepada Masyarakat yang terdiri dari staf pengajar di Program Studi Manajemen Fakultas Ekonomi Universitas PGRI Adi Buana Surabaya.

5) Materi penyuluhan disusun dalam bentuk makalah dan diperbanyak sesuai dengan jumlah peserta penyuluhan.

Dalam program sosialisasi dan pendampingan ini, digunakan beberapa metode, antara lain :

1. Metode ceramah, yaitu digunakan untuk memaparkan materi yang telah disusun oleh Tim Pelaksana.

2. Metode Tanya Jawab, yaitu digunakan untuk merespon sejauh mana tingkat pemahaman peserta sosialisasi terhadap yang telah disampaikan oleh Tim Pelaksana Pengabdian Kepada Masyarakat Fakultas Ekonomi Universitas PGRI Adi Buana Surabaya.

3. Metode diskusi, yaitu pemateri dan peserta melakukan dialog yang membahas masalah seputar pencatatan laporan keuangan sederhana pada pelaku usaha mikro kecil di Desa Pengulu Kecamatan Sidayu Kabupaten Gresik.

4. Metode Simulasi dan Praktek, yaitu digunakan untuk memperlihatkan pentingnya laporan keuangan dalam usha mikro kecil.

\section{HASIL DAN PEMBAHASAN}

Materi Program Kegiatan Pengabdian Kepada Masyarakat (PPM) Prodi Manajemen Fakultas Ekonomi Universitas PGRI Adi Buana Surabaya di Desa Pengulu Kecamatan Sidayu Gresik adalah berupa pendampingan dan sosialisasi/penyuluhan serta praktek pembuatan administrasi dan sistem pencatatan laporan keuangan sederahana pada pelaku usha mikro kecil di desa Pengulu Kecamatan Sidayu Kabupaten Gresik. 
Kegiatan pengelolaan Usaha Mikro Kecil di Desa Pengulu kecamatan Sidayu Kabupaten Gresik diperlukan suatu pencatatan/penyusunan laporan keuangan walaupun sederhana. Sehingga setiap transaksi yang dilakukan dapat terekam dan diketahui apakah aktivitas tersebut mengalami defisit atau surplus. Baik defisit maupun surplus dapat diketahui sumber-sumber mana yang menyebabkan hal tersebut dapat terjadi.sehingga diharapkan melalui pencatatan laporan keuangan, hasila usaha mikro kecil dapat ditingkatkan.

Di akhir kegiatan ini dilakukan evaluasi dan diberikan angket untuk mengetahui tentang tanggapan dari setiap peserta terhadap pelaksana pengabdian kepada masyarakat yang dilakukan oleh Tim Pelaksana Pengabdian dari Universitas Pendidikan Indonesia

\section{DAMPAK DAN MANFAAT KEGIATAN}

Beberapa kegiatan pengabdian masyarakat atau PPM 2019-2020 yang dilakukan di desa Pengulu, Kecamatan Sidayu Kabupaten Gresik adalah peserta dapat memahami perlunya menghadiri sosialisasi pemberdayaan masyarakat yang terkait dengan administrasi dan sistem pencatatan laporan keuangan sederhana ppada usaha mikro kecil dalam meningkatkan hasil olahan secara optimal dan peserta dapat meningkatkan pengetahuan dan keterampilan dalam membuat laporan keuangan sederhana yang lebih terinci dan terstruktur.

Sasaran Kegiatan Pengabdian Masyarakat atau PPM di desa pengulu kecamatan Sidayu kabupaten Gresik adalah pelaku usaha Mikro kecil dan menengah yang sudah ada dan ibu-ibu PKK maupun masyarakat yang berkeinginan untuk mengembangkan kegiatan kewirausahaan dalam meningkatkan perekonomian di Desa Pengulu Kecamatan Sidayu Gresik.

Setelah mengikuti kegigatan pendampingan para pelaku usaha mikro kususnya, diminta untuk membuat catatan dan laporan keuangan sederhana untuk disampaikan ke TIM PPM Program Studi Manajemen Fakultas Ekonomi Universitas PGRI Adi Buana untuk dievaluasi dan diberikan saran dalam pembuatan laporan keuangan di tahun tahun berikutnya.

\section{SIMPULAN}

Kegiatan pengabdian kepada masyarakat dilakukan oleh tim dari Program Studi Manajemen Fakultas Ekonomi Universitas PGRI Adi Buana Surabaya pada bulan Februari dan Maret 2020. Sosialisasi dan Pendampingan tentang adminstrasi dan system pencatatan laporan keuangan sederhana pada pelaku usaha mikro kecil di desa Pengulu Kecamatan Sidayu Kabupaten Gresik merupakan salah satu cara untuk meningkatkan perekonomian

Dengan pendampingan dan sosialisasi ini pula diharapkan para pelaku usaha mikro kecil dan warga mulai memahami pentingnya pencatatan laporan keuangan walaupun secara sederhana tetapi dapat meningkatkan pengetahuan dan keterampilan dalam membuat laporan keuangan yang lebih terinci dan terstruktur. 
Beberapa faktor pendukung kegiatan tersebut antara lain :

1. Para peserta pendampingan dan sosialisasi memeliki kemauan yang besar untuk mendapatkan informasi dan pengetahuan mengenai administrasi dan system pencatatan laporan keuangan pada usaha mikro kecil.

2. Kegiatan pendampingan dan sosialisasi sangat didukung oleh aparat setempat baik secara langsung maupun tidak langsung berpartisipasi secara aktif dalam pelaksanaan pendampingan tersebut. Pihak pemerintah daerah setempat menyediakan fasilitas tempat kegiatan yang cukup representative untuk melaksanakan pendampingan dan sosialisasi terebut serta dukungan untuk mengikuti kegiatan dengan seksama.

\section{SARAN}

1. Pihak pemerintah daerah setempat khususnya dilingkungan kecamatan Sidayu Kabupaten Gresik diharapkan lebih sering melakukan pendampingan dan sosialisasi, terutama untuk peningkatan perekonomian para pelaku usaha mikro kecil dan menengah.

2. Perlu dilakukan kerjasama antara Perguruan Tinggi, Pemerintah Daerah, untuk membentuk desa binaan untuk menciptakan kader-kader pelaku usaha baru dalam rangka untuk meningkatkan kesejahteraan dan kemakmuran masyarakat.

\section{UCAPAN TERIMA KASIH}

Pada kesempatan yang berbahagia ini Tim Pengabdian Program Studi Manajemn Fakultas Ekonomi Universitas PGRI Adi Buana Surabaya mengucapkan terima kasih yang sebesar besarnya kepada :

1. Kepala Desa Pengulu Kecamatan Cerme Kabupaten Gresik yang telah memberikan ijin dan kesempatan untuk melakukan pendampingan dan sosialisasi tentang pentingnya administrasi dan sistem pencatatan laporan keuangan secara sederhana pada pelaku usaha Mikro kecil dan menengah.

2. Para peserta pendampingan dan sosialisasi yang terdiri dari para pelaku usaha Mikro kecil, ibu ibu PKK dan Karang Taruna serta masyarakat desa Pengulu Kecamatan Cerme Kabupaten Gresik yang dengan antusias mengikuti program dari TIM Pengembangan dan Pengabdan Masyarakat Program Studi Manajemen FE UNIPA Surabaya.

\section{DAFTAR PUSTAKA}

Kabupaten Gresik, 2019. Desa di Kecamatan Sedayu. https://gresikkab.go.id/ profil/desa_di_kecamatan_sidayu akses 14 Pebruari 2020.

Sidayu City Explore, tt, a. Sejarah Sedayu. https://sedayuexplore. wordpress.com/sejarahsedayu/ akses 13 Pebruari 2020. 
tt, b. Explorasi Sedayu. https://sedayuexplore.wordpress.com/ekplorasi-sedayu/ akses 13 Pebruari 2020. 